\title{
Impact of digitalization on business environment
}

UDK 338.1

\author{
Aptikasheva P.R. polina.aptikasheva.98@mail.ru \\ Ph.D. Mishura L.G. mishuralg@yandex.ru \\ ITMO University \\ 197101, Russia, St. Petersburg, Kronverksky pr., 49
}

The modern, dynamically developing environment poses new challenges to companies. The development of technologies, automation, and multiple acceleration of processes in the external environment create the need to change traditional approaches to business. The use of standard methods does not allow to achieve leadership and success in the market. The paper deals with the problems and key aspects of digital transformation. The importance of digital talents, new generations and changing the worldview of management is emphasized. The characteristic of the key changes of enterprise management systems in the digital economy is given.

Keywords: digital transformation, management system, digital economy, business transformation, digital frames, digitalization, digital enterprise.

\section{Влияние цифровизации на бизнес-среду}

\section{УДК 338.1}

DOI: $10.17586 / 2310-1172-2021-14-4-66-73$

Научная статья

\author{
Аптикашева П.P.polina.aptikasheva.98@mail.ru \\ Канд. экон. наук Мишура Л.Г. mishuralg@yandex.ru \\ Университет ИТМО \\ 197101, Россия, Санкт-Петербург, Кронверкский пр., д. 49
}

Современная, динамично развивающаяся среда ставит перед компаниями новые цели и задачи. Развитие технологий, автоматизация и многократное ускорение процессов во внешней среде создают необходимость изменения традиционных подходов к бизнесу. Использование стандартных методов не позволяет добиться лидерства, успеха и конкурентных позиций на рынке. В статье рассматриваются проблемы и ключевые аспекты цифровой трансформации, а также подчеркивается важность цифровых талантов, новых поколений и изменения отношения к традиционному менеджменту. Дана характеристика ключевых изменений систем управления предприятием в условиях цифровой экономики и диджитализации.

Ключевые слова: цифровая трансформация, система управления, цифровая экономика, трансформация бизнеса, цифровые фреймы, цифровизация, цифровое предприятие.

\section{Introduction}

Under the influence of the rapid growth and development of high transformational technologies, the global trend today is the digitalization of the business environment, which, in conditions of uncertainty, makes us look and evaluate traditional project management methods in a new way. It is worth noting that digital transformation and digitalization are not the same thing. Digitalization is the introduction of digital technologies (automation) into individual business processes of a company. Digital transformation for each company is implemented in different ways, it can be defined as a strategic business transformation, which implies changing key business decisions according to customer preferences and translating them into an automated format.

Competitive potential of firms is based on their competitive advantage. The more competitive advantage an economic agent manages to attain, the more likely it is to increase its competitive ability. At the current stage of digital economy development there is no room for doubt over the importance and necessity of digital economy technologies, which cannot but encourage firms to approach their competitive advantage in a more responsible way. 
The digital economy, provided by rapid advances in information and communication technology, including the Internet, is shaping a new digital environment where all firms, from digital economy leaders to those wary of digital technologies, must compete. In scientific literature, the changes in the business environment influenced by the digital economy are known as Industry 4.0 or the fourth industrial revolution, which is considered the symbiosis of the traditional material and the virtual world.

\section{Methodology}

The digital economy is defined as "the economic activity that is the result of billions of daily online connections between people, businesses, devices, data and processes. The basis of the digital economy is hyper-connectivity, which means the growing interconnection of people, organizations and machines, which is the result of the Internet, mobile technologies and the Internet of things (IoT) "[3].

The digital economy plays a special role in the successful growth of a business; it is important not only to transform and optimize the internal processes of companies, but also to "understand the users of digital technologies" [4]. Meanwhile, "new technologies and business strategies are transforming not only business processes, but also the ways of creating and selling products and services, the structure and goals of the enterprise, the dynamics of competition and all the rules for business success" [5]. It's important for firms to understand that digital economy technologies amount not merely to process automation, but primarily to new ways of doing business (e.g. improving customer service quality, operational optimization or developing new business models); only then the expectations of economic agents for investments in digital technologies will be met. To unlock the potential of digital economy technologies, firms are required to develop their employees' management and technology skills. If economic agents do not accept new challenges, either deliberately or due to insufficient experience and skills, they lose their competitive advantage.

For the global increase in Russia's competitiveness, the most important condition is the development of high-tech businesses that use modern digital technologies. The changing situation on the world market dictates not only the need for the country's economy to participate in the digitalization process, but also for the so-called digital technological breakthrough, which implies advanced development through fundamentally new solutions in the field of digital technologies creation.

In 2017, the Russian authorities accepted the National Program "Digital Economy of the Russian Federation" with key signs to be achieved by the country by 2024 . To create promising and breakthrough platforms and technologies, as well as the necessary conditions for them or maintain existing ones, each of the directions of development of the digital space is considered.The principal stop-to-stop virtual technology covered by this Program are:

- big data;

- neurotechnology and synthetic intelligence;

- commercial internet

- robotics and sensorics components;

- disbursed ledger systems;

- new manufacturing technology;

- neurotechnology and artificial intelligence;

- disbursed ledger systems

- quantum technology

- wi-fi technology;

- VR technology.

This program will increase digital awareness and literacy among citizens, create conditions and conveniences that will help society develop, discover new knowledge, increase their level of well-being and quality of life by improving the quality of goods and services that are produced in our country using digital technologies. Also, do not forget about the availability of public services, and improving security not only within the country, but also abroad. Digitalization is a universal term that describes the transition from industrialization and its analog technologies to digital innovative technologies and creativity, and shows the process of digital transformation of economic activity and society.

It is fair to ask how digitalization will affect our future. It should be noted that dramatic changes in this area have taken place over the past 50 years. It all started back in the early 90 s, when the Internet just began to spread and Compuserve and AOL. Services appeared, and people began to actively connect to them. The next stage was access to data via a mobile phone and high-speed Internet (5G), as well as artificial intelligence (AI), which is constantly improving every year. Thanks to the development of these technologies, robotization and automation of processes will increasingly be introduced and take root in everyday life, and thereby will affect the change not only in the economy and, but also in individual industries. [1]. 
It will be completely fair to note the fact that the introduction of digital technologies will have a positive effect on changing the transport system and means of transportation. The latest functions and technologies of autonomous driving on autopilot with sensitive sensors that allow the car to slow down or keep a safe distance from another vehicle (vehicle), give hints to the driver when parking and locking the system, before renting electric scooters, bicycles and other vehicles.

- Digitalization transforms not only approaches to doing business, simplifies the lives of citizens, but also affects the change in traditional professions. A particularly striking example is the healthcare sector, since in connection with the pandemic, e-health applications, telemedicine, are increasingly developing, which will allow you to get away from paper documentation and immediately convert patient data into their personal online card, where the entire history will be stored. diseases and simplify the work of medical personnel. The same applies to lawyers, their sphere will be more automated, additional digital services will be added or completely disappeared. Coffee corners are actively appearing, where the barista is replaced by a robot, which, according to your order, will make coffee and have a short conversation.

- Digitalization is having an increasing impact on the financial sector. The well-known blockchain technologies today allow the use of trilateral agreements for secure transactions - smart contracts, new forms of corporate financing, which are encrypted thanks to a special algorithm - hashing. Bitcoin virtual currency allowing investment in companies through ICOs (Initial Coin Offers) or STOs (Security Token Offerings) and much more.

Typical fields of action are:

- To form a culture of innovation, thanks to which it will be possible to create and improve high technologies for their implementation in business processes and business models, digital services.

- Train employees to prepare them for the challenges of the digital age and empower them to participate in digital change.

- Development of a strategy for the implementation and rooting of digital innovations, that is, a company's action plan for digitalization.

- Train employees to prepare them for the challenges of the digital age and empower them to participate in digital change.

- Bringing the marketing and sales activities of the company to digitalization.

- Development of digital procedures and processes: Say goodbye to paper files by introducing processes and procedures in the company, some of which need to be radically rethought because of the digital transition.

- Dealing with data that arises within the company, in connection with the activities of a company or with customers. New service and business models can be developed from data.

The digitalization of a business is the driving force behind its promotion. Its main advantages are:

- increasing efficiency and establishing communication skills - both internal and external;

- cross-selling / upselling opportunities - reaching a new level of customer service and encouraging them to purchase more products;

- saving the main resource - time and increasing productivity, the transition to automated production processes and other business processes at the enterprise;

- competitive opportunity through improved customer experience and overall workflow optimization [2].

Do not forget that the coronavirus has made its own adjustments to the digitalization of business. More flexible, adaptive companies tend to survive, with better tools in their arsenal to be agile, respond quickly to changes, and better adapt to changing market conditions.

Digitalization affects all the most important spheres of life. These include:

- healthcare,

- banking,

- restaurant business,

- economics,

- trade,

- logistics,

- real estate,

- education,

- insurance,

- marketing,

- and others.

Digitalization of processes has a clear goal: to satisfy customer needs and remove objections. This is exactly what is needed in the modern financial world.

In addition to meeting customer needs, digitalization for business has other goals:

- providing convenient interaction between the company and the client; 
- prompt solution of client's questions, removal of objections and stimulation to purchase;

- automation of internal work processes, improvement of communication within the company;

- improving the quality of service;

- providing a wide range of tools for selling a product or service;

- improvement of product quality, modernization of delivery services, payment.

Business digitalization helps to take a company to the next level, increase customer loyalty to the brand, and implement new tools quickly and efficiently. Marketing costs decrease, sales conversion improves, and competitiveness grows.

But there is also a downside to the digitalization of the economy, namely, the problems that society is facing right now. Access to relatively inexpensive technologies and limited opportunities for efficient use can lead to uneven and inequitable sharing of benefits. Firstly, residents of rural areas, people with disabilities or limited rights may suffer, and those who have a low level of literacy or education will not bypass this either. There is such a theory that too fast and widespread use and implementation of digital technologies and products, robotization and all kinds of platforms will contribute to a sharp reduction in jobs and many professions will lose their relevance. This will lead to increased inequality in income distribution and social stratification between rich and poor. Negative consequences can lead to a violation of the privacy and life of customers and users, as they will have to defend their interests and point of view. It is possible that digital crime will increase and companies, both large and small, will have to defend their interests and respond to such behavior in time. High technologies inevitably create, in addition to the convenience and simplification of processes for some, regulatory, ethical and other forms of problems with an enhanced ability of devices to make decisions based only on algorithms and machine learning codes.

\section{Digitalization in healthcare}

During the coronavirus, the popularity of e-health applications and telemedicine has increased dramatically and now has a rather important role. The most popular applications currently in use in the US are One Medical, Teladoc, Amwell, GoodRx's HeyDoctor, PlushCare and others. For example, appointments through PlushCare alone increased by $70 \%$, while Amwell app usage increased by $158 \%$ in the US and $650 \%$ in Washington state alone. Telemedicine allows clinicians to be safe by keeping a safe distance from clients and can easily channel care and limited funds for emergencies. And it's not just the coronavirus, as it can help for other serious illnesses as well, such as cancer, heart or brain disease.

The Internet of Things (IoT) is used for real-time tracking and updating of various online databases in the US, UK and China, real-time tracking of high-risk areas in Korea (Coronamap.live; Wuhanvirus.kr), virtual clinics (PingAn, China) spreading public information via WhatsApp in Singapore.

Big data is used to model disease activity, potential increase in incidence and distribution zones; modeling the preparedness and vulnerability of countries in the fight against coronavirus; business modeling of pharmaceutical supply for various medicines, etc.

Examples of the use of artificial intelligence (AI): detecting COVID-19 on chest x-rays (Beijing hospital) and predicting disease progression based on clinical data and images; AI for automatic diagnosis of non-COVID-19 medical conditions (Zhongshan Ophthalmology Center, China); medical chat bots.

Blockchain can be used to: produce and distribute COVID-19 vaccines as soon as they are available; insurance claims in case of illness or death related to COVID-19; Distribution of conventional medicines delivered to local pharmacies or to the patient's home address.

\section{Banking}

For banks, digitalization implies not only the provision of banking products and services via Internet banking and mobile banking. Banks need to carry out significant work on the full coordination of service channels, to connect them in one system, that is, to engage in omni-channel, building a digital banking model.

The digital banking model presupposes the development of a digital strategy, the main goal of which is to create a fundamentally new and high-quality service that provides customers with maximum comfort when using banking products and services, which in turn speaks of the bank's competitiveness in the new realities. Today, to retain a client, to gradually expand its client base (in conditions when the market is practically divided), it is not enough for a bank to offer the client only classic settlement and cash services. It is very important for him to be able to offer the client such a service or service that can simplify the conduct of his day-to-day operational activities and will allow him to effectively manage the liquidity of the business.

Several large digital banks are successfully operating in Russia today - Tinkoff Bank, Rocketbank, Otkritie FC, Touch Bank of OTP Bank. 
Alfa Group in 2017 announced the creation of an independent digital bank, which will operate under a separate license and compete with Alfa Bank.

Sber first launched SMS Bank and Sber-Online, and then a mobile application. Already now $99 \%$ of credit decisions for individuals are made automatically.

Everybody wins when they go digital. The client saves on commissions for transfers and spends less time on operations, and we save on service. So, with the transition to digital services, we can optimize costs. Employees are being reassigned from simple tasks that can already be done in remote maintenance services to more complex ones. Already in 2018, 83\% of Sberbank's clients used at least one digital product. The Sberbank ecosystem contributes to the growth of the audience and brand awareness. Three years ago, about $83 \%$ of Sberbank's customers at that time used at least one digital product. In 2020, Sberbank's revenue from the non-financial sector increased from 26.4 billion to 71.4 billion rubles - an average of 2.7 times compared to the previous figure, according to IFRS statements. E-commerce (this includes e-commerce and logistics services. The main companies in this sub-segment are Sberlogistics, SberMarket, Samokat). Sberbank's revenue in this area at the end of 2020 reached 12.9 billion rubles against 0.3 billion rubles in 2019 [4].

\section{Restaurant}

Restaurants were the very first to be hit by the coronavirus, and the first had to switch to digital in order to try to maintain their positions and not close forever.

However, the order-to-order strategy may save some restaurants, particularly those who have previously had takeout menus and who have partnered with delivery companies such as Uber Eats, Glovo, Deliveroo and others.

Some of them may even switch to the Ghost kitchen model on an ongoing basis and continue to deliver ready-made meals after the coronavirus outbreak is over. As Google recently reported, searches for Uber Eats, DoorDash, Postmates and Grubhub in the US have increased 53\% over the past month. Uber Eats rose 70\%, followed by DoorDash with 55\%, Grubhub (46\%) and Postmates (42\%).

\section{E-commerce}

At a time of rapid technological progress, e-business development is accompanied by e-commerce, which allows participants to open new opportunities and horizons.

Let's highlight the benefits of e-commerce:

1. Promotes the development of competition and competitiveness of goods and services

2. Contributes to the mobilization of temporarily free financial resources for the implementation of specific investments through the development of electronic trading in securities, the transfer of credit and deposit operations of commercial banks to the online mode.

3. Allows the state to regulate entrepreneurial activity more effectively, thereby contributing to its development business.

4. Reduces the cost of payments and opens new opportunities for product promotion, new sources of income for

5. Provides great opportunities for marketing research "niches" in the market.

6. Influences the change in market structure: small firms successfully compete with large enterprises, contributing to a positive increase in competition.

7. Allows to increase non-cash payments through the development of electronic payments, to reduce the risks associated with the receipt, storage and accounting of funds.

8. Allows the use of social networks in e-commerce transactions, expands the possibilities for conducting transactional business.

9. Increases the physical accessibility of online commerce, as it does not know queues and distances.

10. Reduces the budget costs for their provision, significantly reduces the time for receiving services to their recipients when transferring public services to electronic format.

11. Accelerates money circulation, thereby reducing the money supply.

\section{Logistics}

Digitalization in shipping and transportation companies also plays an important role as it helps to optimize the business. With the introduction of new digital technologies, document flow is improved, work with passengers or cargo will take to a fundamentally new level, and, of course, the costs of organizing logistics are reduced. The bureaucratic burden is reduced, many processes are automated and simplified.

As a result, digitalization in this area leads to increased revenues, cost optimization, and better customer relationships. Service provisioning, costing calculators, tracking maps, and many other tools help take your business to the next level. 
Logistic processes are always inextricably linked with information about the movement of cargo, vehicles, etc. The introduction of systems in logistics to control the location of vehicles and radio frequency coding (RFID) systems for cargo, as well as the implementation of smart contracts create a new digital logistics.

One of the most important elements in digital logistics is electronic document management. Digital transport documents require the use of big data technologies and especially analytical methods.

The use of electronic document management in the implementation of freight traffic creates the preconditions for the development of digital logistics as an innovative technology for managing information flows in the logistics network at all hierarchical levels. The preparation of paper documentation and the delay in delivery associated with its registration account for $10-15 \%$ of transport costs. With the introduction of digital logistics based on legally recognized electronic document management, these costs and delivery times can be reduced by $20-40 \%$. [16]

\section{Real estate}

As practice shows, the real estate sector also needs digitalization. The introduction of new technologies and tools helps to improve the relationship between the client and the company. This will allow clients, before a real online inspection, to consider and study the property in more detail, calculate profitable options, set all the necessary conditions and parameters to satisfy the request as much as possible.

It is necessary to develop functional sites, applications, interactive interaction, apply unique tools to maintain competitiveness and maximum convenience for customers. With the active use of artificial intelligence in 2030, innovative solutions will be able to ensure GDP growth by $11.3 \%$, and the real estate sector will actively use these solutions.

Development will take place in more complex areas, for example, big data algorithms will be able to recognize voices and make decisions.

In the future, thanks to systems based on artificial intelligence, it will be possible to minimize the percentage of wrong decisions due to lack of data.

Artificial intelligence (AI) is a general term for technologies that can perceive the environment, independently learn to respond to signals or make decisions autonomously. These are computer programs capable of learning, perception, planning, thought analysis and self-correction.

Artificial intelligence can be divided into four functional categories:

1. Automating intelligence: automation of manual / cognitive and typical / non-standard tasks.

2. Supportive intelligence: faster and more efficient task completion.

3. Developing intelligence: help in making the right decisions.

4. Autonomous intelligence: automation of decision-making processes without human intervention.

The use of artificial intelligence in the real estate sector will not only improve the efficiency of operational tasks, but also change decision-making processes. [17]

\section{Education System}

The field of education, thanks to COVID-19, has made a big leap in digitalization, as practice shows. Thanks to the Internet, it has become easy to transfer schoolchildren and students to the online format. All documents are now in electronic format: journals, diaries, grade books, all necessary and important information is published on official websites, chats. Educational institutions are equipped with modern technological tools: high-speed computers, interactive whiteboards, tablets, projectors and other gadgets. At the same time, the traditional format of full-time education with a teacher remains, but digitalization in education makes the learning process more effective, and contributes to the development of responsibility and self-discipline among students, increasing the effectiveness of teachers and educators, where they already act as assistants and mentors. Thanks to the instructions of the Minister of Science and Higher Education of the Russian Federation V.N. Falkov at a meeting of the working group on the collection of information on how effectively digital resources are used, this rating was compiled by the team "Yurayt.Statistics" based on the data used by students and teachers of the educational platform "Yurayt".

129666 students, 17923 teachers and 836 universities were analyzed to compile this ranking. And the following universities are in the Top 10 leaders in the use of digitalization in the educational process in terms of the number of conditional days of using the Yurayt platform:

1) Russian Academy of National Economy and Public Administration under the President of the Russian Federation (Moscow) - 16127

2) Ural State Law University (Yekaterinburg) - 9955

3) Russian State University of Justice (Moscow) - 9006

4) Financial University under the Government of the Russian Federation (Moscow) - 8648

5) Irkutsk State University - 5445 
6) Moscow State Law University O.E. Kutafina - 4787

7) Russian University of Economics named after G.V. Plekhanov (Moscow) - 4419

8) Kuban State University (Krasnodar) -3898

9) National Research University Higher School of Economics - 3114

10) Russian Customs Academy (Lyubertsy) - 2804

The first three universities retain their leadership due to the fact that these universities have a large branch network throughout Russia, and this allows them to ensure high and uniform brand standards in the field of education.

With regards to the field of law, three universities of the Ural State Law University, the Moscow State Law University named after O.E. Kutafina and the Russian State University of Justice have successfully applied in practice the inclusion of legal materials in their educational process and remain a reference point for Russian education in the field of law.

NRU HSE is one of the first universities at the forefront of introducing digitalization into the educational process, as it is constantly modernized and innovatively approaches the education system of both students and teachers, using a high level of their trust.

ISU and KubSU are excellent examples of regional universities, which prove that not only Moscow and St. Petersburg universities are successfully using digital products in their educational activities. The regions keep up with the dynamically developing and changing educational environment, but they are constantly improving their digital environment, which allowed them to achieve high positions in the ranking.

The Russian Customs Academy is a good example of a departmental university that is also following a transformational path. [18]

\section{Conclusion}

Digital transformation is the engine of the economy not only of one state, but of the entire world, which allows changing the forms of economic relations. In the age of information technology, to exist in the long term, businesses in absolutely any field need a digital transformation and a strategy for a successful transition. Digitalization is an integral process of growth and development of any business in connection with the rapid and changing market trends. The latest technologies dictate their own rules, hinting that you need to be flexible, keep up with the times, keep your finger on the pulse and actively adapt to maintain a competitive position. Changes in the approach to business allow the introduction of modern and innovative technologies, improve interaction with customers and increase their loyalty, increase performance indicators and lead to inevitable growth and development.

\section{Refrences}

1. PROGRAM "Digital Economy of the Russian Federation" [Electronic resource] URL: http://static.government.ru/media/files/9gFM4FHj4PsB79I5v7yLVuPgu4bvR7M0.pdf (date of the application: 17.09.2021)

2. What is digitalization? [Electronic resource] URL:

https://innolytics-innovation.com/what-is-digitalization/ (date of the application: 14.09.2021)

3. Business digitalization [Electronic resource] URL:

https://wezom.com.ua/blog/didzhitalizatsija-biznesa (date of the application: 18.09.2021)

4. Sberbank (digital business) [Electronic resource] URL: https://clck.ru/Xdps8 (date of the application: 11.09.2021)

5. Business digitalization concept: spheres and necessity [Electronic resource] URL: https://evergreens.com.ua/ru/articles/business-digitalization.html (date of the application: 10.09.2021)

6. DIGITALIZATION AND DIGITAL TRANSFORMATION OF BUSINESS: CONTEMPORARY CHALLENGES AND TRENDS [Electronic resource]

URL: $\quad$ https://cyberleninka.ru/article/n/tsifrovizatsiya-i-tsifrovaya-transformatsiya-biznesa-sovremennye-vyzovy-itendentsii (date of the application: 10.10.2021)

7. Shirinkina E.V. - A multifactor model for the development of digitalization of business processes of enterprises // Theoretical and Applied Economics. - 2021. - No. 2. - P. 1 - 10. DOI: 10.25136/2409-8647.2021.2.32665

8. Business digital transformation: models and algorithms DOI: $10.18334 / \mathrm{ce} .12 .9 .39332$ [Electronic resource] URL: https://www.researchgate.net/publication/328423718_Cifrovaa_transformacia_biznesa_modeli_i_algoritmy (date of the application: 11.10.2021)

9. Digitalization processes in small and medium-sized companies in a pandemic № 2. - C. 299-312. doi: 10.18334/epp.11.2.111637

10. Digital transformation of business in 2021 - conditions, technologies, directions [Electronic resource] URL: https://eternalhost.net/blog/perevody/tsifrovaya-transformatsiya-biznesa (date of the application: 12.10.2021) 
11. From "digitalization" to "digital transformation" directions [Electronic resource] URL: https://www.crn.ru/news/detail.php?ID=153070 (date of the application: 12.10.2021)

12. Digitalization of business processes: benefits for $\mathrm{B} 2 \mathrm{~B}$ companies [Electronic resource] URL: https://www.agora.ru/blog/cifrovizacija-biznes-processov-preimushhestva-dlja-b2b-kompanij/ (date of the application: 15.10.2021)

13. Digital transformation - an innovative business model [Electronic resource] URL: http://www.meconomy.ru/art.php?nArtId=6610 (date of the application: 15.10.2021)

14. Digitalization of business processes [Electronic resource] URL: https://severstalssc.com/services/czifrovizacziyabiznes-proczessov/ (date of the application: 18.10.2021)

15. Competitive digitalization [Electronic resource] URL: https://econs.online/articles/techno/konkurentnayatsifrovizatsiya/ (date of the application: 19.10.2021)

16. Digitalization in modern transport logistics [Electronic resource] URL: https://thisislogistics.blogspot.com/2020/01/blog-post.html (date of the application: 14.11.2021)

17. Artificial Intelligence in Real Estate sphere [Electronic resource] URL: https://www.pwc.ru/ru/industries/realestate/digital-real-estate/artificial-intelligence-in-real-estate.html (date of the application: 14.11.2021)

18. National ratings of digital activity of universities and scientific schools in Russia [Electronic resource] URL: http://www.unkniga.ru/vishee/11291-natsionalnye-rejtingi-tsifrovoy-aktivnosti-vuzov.html (date of the application: 14.11.2021)

Статья поступила в редакиию 22.10.2021 г Received 22.10.2021 